\title{
Gambaran Pengetahuan dan Sikap Ibu Hamil tentang Prenatal Yoga di Puskesmas Putri Ayu Kota Jambi
}

\author{
Sri Maharani \\ Program Studi DIII Kebidanan STIKes Baiturrahim Jambi \\ Email:maharanibarus@gmail.com
}

Submitted : 07/12/2019

Accepted: 06/02/2020

Published:14/03/2020

\begin{abstract}
Anxiety and fear experienced by the mother, especially primipara, can prolong the duration of labor and increase the incidence of labor by action, namely labor with cesarean section. Mental health including pregnancy anxiety has been proven to be reduced or eliminated through physical exercise. One of the recommended physical exercises is yoga because it is easy to do and is very beneficial for physical fitness and psychology. Yoga in pregnancy is more effective in reducing anxiety and depression. This study aims to describe the knowledge and attitudes of pregnant women about prenatal yoga. Quantitative research design. The subjects in this study were pregnant women trimester I, II and III in the working area of the Putri Ayu Public Health Center in Jambi. Research subjects were given questionnaires to measure the knowledge and attitudes of pregnant women regarding Prenatal Gentle Yoga. The study was conducted in the working area of the Putri Ayu Public Health Center in Jambi. The data collected was analyzed univariately. The results of the study revealed that 32 mothers who took classes in pregnant women in the working area of Putri Ayu Health Center had less knowledge about prenatal gentle yoga, namely 18 mothers (56.2\%) and had a positive attitude of 25 mothers (78\%). It is recommended for health workers to provide information about some of the development activities that pregnant women can do to provide comfort during pregnancy, for example with prenatal gentle yoga.
\end{abstract}

Keyword: attitude, knowledge, pregnant women, prenatal yoga

\begin{abstract}
Abstrak
Kecemasan dan ketakutan yang dialami oleh ibu bersalin terutama primipara dapat memperpanjang durasi persalinan dan meningkatkan kejadian persalinan dengan tindakan, yaitu persalinan dengan seksio sesarea. Kesehatan mental termasuk kecemasan kehamilan terbukti dapat dikurangi atau dihilangkan melalui latihan fisik. Salah satu latihan fisik yang direkomendasikan adalah yoga karena mudah untuk dilakukan dan sangat bermanfaat untuk kebugaran fisik dan psikologi. Yoga dalam kehamilan lebih efektif dalam menurunkan kecemasan dan depresi. Penelitian ini bertujuan untuk menggambarkan pengetahuan dan sikap ibu hamil tentang prenatal yoga. Desain penelitian kuantitatif. Subjek dalam penelitian ini adalah ibu hamil trimester I, II dan III di wilayah kerja Puskesmas Putri Ayu Kota Jambi. Subjek penelitian diberikan kuesioner untuk mengukur pengetahuan dan sikap ibu hamil mengenai Prenatal Gentle Yoga. Penelitian dilakukan di Wilayah kerja Puskesmas Putri Ayu Kota Jambi. Data yang terkumpul dianalisis secara univariat. Hasil penelitian diketahui dari 32 ibu yang mengikuti kelas ibu hamil di Wilayah Kerja Puskesmas Putri Ayu memiliki pengetahun kurang tentang prenatal gentle yoga yaitu 18 ibu $(56,2 \%)$ dan memiliki sikap positif yaitu $25 \mathrm{ibu}(78 \%)$. Disarankan kepada tenaga kesehatan untuk memberikan informasi mengenai beberapa perkembangan aktivitas yang dapat dilakukan ibu hamil untuk memberikan kenyamanan selama kehamilan contohnya dengan prenatal gentle yoga.
\end{abstract}

Kata Kunci : ibu hamil, pengetahuan, prenatal yoga, sikap

\section{PENDAHULUAN}

Sekitar $6 \%$ dari populasi umum mengalami gangguan cemas, generalized anxiety disorder (GAD) merupakan gangguan yang paling sering ditemui, terjadi pada $2-4 \%$ populasi. Kecemasan dan ketakutan yang dialami oleh ibu 
bersalin terutama primipara dapat memperpanjang durasi persalinan dan meningkatkan kejadian persalinan dengan tindakan, yaitu persalinan dengan seksio sesarea (OR 26,9 CI 95\%) dan vakum ekstraksi (OR 4,5 CI 95\%). Felman et al juga menemukan lebih dari $12 \%$ ibu-ibu yang pernah melahirkan mengatakan bahwa mereka mengalami cemas pada saat melahirkan dimana pengalaman tersebut merupakan saat-saat tidak menyenangkan dalam hidupnya.

Kecemasan akan dirasakan berbeda selama kehamilan dan kecemasan trimester ketiga lebih tinggi dibanding trimester sebelumnya. Kehamilan dengan kecemasan akan mempengaruhi lingkungan intrauterine dan perkembangan janin. Kecemasan berpeluang meningkatkan 3 kali ketakutan dalam persalinan dan berpeluang 1,7 kali meningkatkan kejadian sectio cesarea. Kesehatan mental termasuk kecemasan kehamilan terbukti dapat dikurangi atau dihilangkan melalui latihan fisik. Salah satu latihan fisik yang direkomendasikan adalah yoga karena biaya rendah, mudah untuk dilakukan dan sangat bermanfaat untuk kebugaran fisik dan psikologi. Yoga dalam kehamilan lebih efektif dalam menurunkan kecemasan dan depresi.

Yoga merupakan suatu bentuk seni ilmu pengetahuan kuno dan perawatan kesehatan yang tertua dan berasal dari india, yang semula dirancang dan dibentuk untuk memperkuat dan membentuk sikap tubuh serta menenangkan dan memusatkan pikiran untuk masuk kedalam kondisi meditasi, namun yoga berhasil diadaptasi untuk berbagai kepentingan dan gaya hidup dari orang-orang barat, sehingga sekarang yoga dikenal sebagai salah satu seni olahraga.

Yoga antenatal adalah sebuah ilmu yang menjelaskan kaitan antara fisik, mental, dan spiritual manusia untuk mencapai kesehatan yang menyeluruh. Melakukan latihan yoga pada saat hamil, akan mempersiapkan tubuh maupun pikiran untuk siap dan tegar menghadapi masa persalinan Pada saat melakukan gerakan yoga, hipotalamus akan mempengaruhi sistem saraf otonom yaitu menurunkan aktivitas saraf simpatis dan meningkatkan aktivitas saraf parasimpatis. Yoga akan menghambat peningkatan saraf simpatis sehingga hormon penyebab disregulasi tubuh dapat dikurangi jumlahnya. Sistem saraf parasimpatis memberi sinyal untuk mempengaruhi pengeluaran katekolamin. Akibatnya, terjadi penurunan detak jantung, irama nafas, tekanan darah, ketegangan otot, tingkat metabolisme, dan produksi hormon penyebab kecemasan atau stres. Yoga mempengaruhi pula hipotalamus untuk menekan sekresi CRH yang akan mempengaruhi kelenjar hipofisis lobus anterior untuk menekan pengeluaran hormon ACTH sehingga produksi hormon adrenal dan kortisol menurun serta memerintahkan kelenjar hipofisis lobus anterior mengeluarkan hormon endorpin.

Dalam latihan yoga, kita menggabungkan dan menyatukan pikiran, tubuh dan ruh kedalam satu kesatuan yang saling melekat dan seimbang. Yoga juga merupakan alat yang kuat, menyeluruh dan membawa perubahan yang dapat menenangkan pikiran dan membuat menjadi lebih terpusat. Sikap tubuh, kesadaran pernapasan, dan teknik relaksasi akan mengembangkan kecerdasan intuisi alamiah dan membantu pikiran untuk dapat terpusat pada satu hal disatu waktu. Ketika pikiran terpusat, system saraf, system sirkulasi dan system pernapasan akan bergerak lebih lambat. Tubuh dan pikiran akan menjadi lebih santai, lebih tenang, berfikir dengan lebih jernih, dan akan merasa lebih dapat berkonsentrasi.

Bersamaan dengan pikiran yang lebih tenang, tubuh terbuka untuk melepaskan ketegangan dan emosi yang telah tertahan untuk waktu yang lama. Emosi akan menjadi seimbang, tubuh akan mengembangkan kekuatan yang seimbang 
sehingga medatangkan kelenturan dan kestabilan.

Yoga juga merupakan sebuah alat terapi. Berbagai penyakit, keluhan pada ibu hamil dapat dilepaskan atau dapat dikurangi bahkan dihilangkan melalui berbagai posisi, gerakan/ asanas tertentu dan latihan pernafasan.

Pengetahuan merupakan adalah hasil pengindraan manusia, atau hasil tahu seseorang terhadap objek melalui indra yang dimilikinya (mata, hidung, telinga dan sebagainya). Dengan sendirinya pada waktu pengindraan sehingga menghasilkan pengetahuan tersebut sangat dipengaruhi oleh intensitas perhatian dan persepsi terhadap objek. Sebagian besar pengetahuan seseorang diperoleh melalui indra pendengaran (telinga), dan indra penglihatan (mata).

Apabila pengetahuan itu mempunyai sasaran yang tertentu, mempunyai metode atau pendekatan untuk mengkaji objek tersebut sehingga memperoleh hasil yang dapat disusun secara sistematis dan diakui secara universal, maka terbentuklah disiplin ilmu. Dengan perkataan lain, pengetahuan ini dapat berkembang menjadi ilmu apabila memenuhi kriteria mempunyai objek kajian, mempunyai metode pendekatan, bersifat universal (mendapat pengakuan secara umum).

Sikap (attitude) merupakan konsep paling penting dalam psikologi sosial yang membahas unsur sikap baik sebagai individu maupun kelompok. Banyak kajian

\section{HASIL DAN PEMBAHASAN}

\section{Analisis Univariat}

\section{Karakteristik Subjek Penelitian}

Tabel 1. menunjukkan sebagian besar responden berumur reproduktif 20-35 tahun dengan jumlah 28 responden $(87,5 \%)$. Responden sebagian besar bekerja sebagai yang dilakukan untuk merumuskan pengertian sikap, proses terbentuknya sikap maupun perubahan.

Sikap merupakan reaksi atau respon seseorang yang masih tetutup terhadap suatu stimulus atau objek yang sudah melibatkan faktor pendapat dan emosi bersangkutan.

Berdasarkan uraian diatas maka peneliti tertarik untuk melakukan penelitian tentang "Gambaran Pengetahuan dan Sikap Ibu Hamil tentang prenatal yoga di Puskesmas Putri Ayu Kota Jambi”

\section{METODE PENELITIAN}

Penelitian ini merupakan penelitian kuantitatif dengan pendekatan cross sectional. Populasi penelitian ini adalah seluruh ibu hamil yang berkunjung di Puskesmas Putri Ayu Kota Jambi yang berjumlah 320 orang. Sampel pada penelitian ini berjumlah 32 orang. Yang dipilih secara acak dipilih secara Accidental Sampling. Alat pengumpulan data menggunakan kuesioner yang berisi 15 item pertanyaan pengetahuan dan 10 item pertanyaan sikap.

Pelaksanaan penelitian keseluruhan selama 3 bulan mulai dari bulan Maret-Juli Tahun 2019 di Wilayah Kerja Puskesmas Putri Ayu Kota Jambi. Penentuan lokasi dilakukan dengan pertimbangan jumlah kunjungan ibu hamil terbanyak diKota Jambi adalah di Puskesmas Putri Ayu Kota Jambi.

IRT dengan jumlah 27 responden $(84,4 \%)$ dan sebagian besar responden berpendidikan SAM/SMK yaitu 18 orang responden $(56,3 \%)$. 
Tabel 1. Distribusi Karakteristik Subjek

\begin{tabular}{lcc}
\hline \multirow{2}{*}{ Karakteristik } & \multicolumn{2}{c}{ Jumlah (\%) } \\
\cline { 2 - 3 } & $\mathrm{n}=32$ & $\%$ \\
\hline Umur & 28 & 87,5 \\
20-35 tahun & 4 & 12,5 \\
>35 tahun & & \\
Pekerjaan & 27 & 84,4 \\
IRT & 4 & 12,5 \\
Swasta & 1 & 3,1 \\
Honorer & 0 & 0 \\
PNS & & \\
Pendidikan & 11 & 34,3 \\
SMP & 18 & 56,3 \\
SMA/SMK & 3 & 9,4 \\
PT &
\end{tabular}

Tabel 2. Distribusi Pengetahuan Ibu Hamil tentang Prenatal Gentle Yoga

\begin{tabular}{lcc}
\hline \multirow{2}{*}{ Pengetahuan } & \multicolumn{2}{c}{ Jumlah (\%) } \\
\cline { 2 - 3 } & $\mathrm{n}=32$ & $\%$ \\
\hline Baik & 4 & 12,5 \\
Cukup & 10 & 31,3 \\
Kurang & 18 & 56,2 \\
\hline
\end{tabular}

Berdasarkan hasil penelitian pada tabel 2. didapatkan hasil bahwa pengetahuan ibu hamil tentang prenatal gentle yoga memiliki pengetahuan baik yaitu 4 ibu (12,5\%), memiliki pengetahuan cukup yaitu $10 \mathrm{ibu}(31,3 \%)$ dan memiliki pengetahuan kurang yaitu 18 ibu $(56,2 \%)$. Dapat disimpulkan bahwa ibu memiliki pengetahuan kurang.

Pengetahuan merupakan hasil pengindraan manusia, atau hasil tahu seseorang terhadap objek melalui indra yang dimilikinya (mata, hidung, telinga dan sebagainya). Dengan sendirinya pada waktu pengindraan sehingga menghasilkan pengetahuan tersebut sangat dipengaruhi oleh intensitas perhatian dan persepsi terhadap objek. Sebagian besar pengetahuan seseorang diperoleh melalui indra pendengaran (telinga), dan indra penglihatan (mata).

Kurangnya pengetahuan ibu dikaitkan dengan pendidikan ibu dimana dari hasil karakteristik didapatkan pendidikan ibu mayoritas SMA/SMK yaitu 18 orang
$(56,3 \%)$, sedangkan yang pendidikan paling rendah adalah PT yaitu 3 ibu $(9,4 \%)$. Pendidikan adalah suatu usaha untuk mengembangkan kepribadian dan kemampuan di dalam dan luar sekolah berlangsung seumur hidup. Semakin tinggi pendidikan semakin banyak pula peluang seseorang untuk mengembangkan kepribaian dan kemampuan seseorang tersebut untuk mendapatkan informasi yang lebih baik.

Selain itu pengetahuan dikaitkan pula dengan usia ibu. Usia mempengaruhi daya tangkap dan pola pikir seseorang. Semakin bertambah usia akan makin bertambah pula daya tangkap dan pola pikirnya, sehingga pengetahuan yang diperolehnya semakin membaik. Hal ini tidak sesuai dengan hasil penelitian dikarenakan mayositas usia ibu dalam penelitian ini adalah berusia $20-35$ tahun yaitu 28 ibu (87,5\%). Hal ini dikarenakan beberapa faktor lain yang mempengaruhi, salah satunya adalah sumber informasi dan lingkungan sekitar.

Hasil penelitian ini sejalan dengan hasil penelitian yang dilakukan oleh Wina Fitriani tahun 2017 dengan judul "Hubungan Pengetahuan Ibu Hamil Dengan Sikap Ibu Hamil Tentang Senam Hamil Di Puskesmas Sawa Kabupaten Konawe Utara Tahun 2017" hasil penelitian ada hubungan yang signifikan antara pengetahuan ibu hamil dengan sikap ibu hamil terhadap senam hamil di puskesmas Sawa Kabupaten Konawe Utara ( $\mathrm{p}=0,023 ; \mathrm{X} 2=7,588)$.

Tabel 3. Distribusi Sikap Ibu Hamil tentang Prenatal Gentle Yoga

\begin{tabular}{lcc}
\hline \multirow{2}{*}{ Sikap } & \multicolumn{2}{c}{ Jumlah (\%) } \\
\cline { 2 - 3 } & $\mathrm{n}=32$ & $\%$ \\
\hline Positif & 25 & 78 \\
Negatif & 7 & 22 \\
\hline
\end{tabular}

Berdasarkan tabel 3 didapatkan hasil bahwa sikap ibu tentang prenatal gentle yoga paling banyak memiliki sikap positif yaitu 25 ibu (78\%). Sikap merupakan reaksi atau respon seseorang yang masih tetutup terhadap suatu stimulus atau objek yang 
sudah melibatkan faktor pendapat dan emosi bersangkutan.

Sikap seseorang dipengaruhi oleh faktor internal dan eksternal. Faktor internal tersebut antara lain faktor yang terdapat dalam diri pribadi manusia itu sendiri dan faktor eksternal yaitu faktor yang terdapat dari luar diri manusia itu sendiri. Sikap belum merupakan tindakan (reaksi terbuka) atau aktivitas, akan tetapi merupakan predisposisi perilaku (tindakan) atau reaksi tertutup.

Menurut asumsi peneliti tidak ada kesenjangan antara hasil penelitian dengan teori. Bahwa dari hasil penelitian didapatkan hasil mayoritas ibu memiliki sikap positif. Semakin tinggi pengetahuan seseorang memiliki kaitan positif kepada sikap seseorang tersebut. Selain itu sikap dipengaruhi pula oleh pengalaman, pengaruh orang lain, sumber informasi dan lingkungan sekitar.

\section{SIMPULAN}

Pengetahuan ibu hamil kurang tentang Prenatal Gentle Yoga di Wilayah Kerja Puskesmas Putri Ayu tahun 2019 yaitu sebanyak 18 ibu (56,2\%). Sikap ibu hamil positif tentang Prenatal Gentle Yoga di Wilayah Kerja Puskesmas Putri Ayu tahun 2019 yaitu sebanyak 25 ibu (78\%).

Pengetahuan mengenai prenatal yoga serta mencari informasi melalui media baik cetak maupun elektronik tentang prenatal yoga bagi ibu hamil penting agar dapat melatih pernafasan selama hamil dan melakukan rileksasi selama kehamilan, sehingga dapat menjalani kehamilan dengan nyaman.

\section{DAFTAR PUSTAKA}

Davis, K., Goodman, S. H., Leiferman, J., Taylor, M. \& Dimidjian, S. (2015) Complementary therapies in clinical practice a randomized controlled trial of yoga for pregnant women with symptoms of depression and anxiety.
Complement Ther Clin Pract, 21 (3): 166-72.

Fitriani W. 2017. Hubungan Pengetahuan Ibu Hamil Dengan Sikap Ibu Hamil Tentang Senam Hamil Di Puskesmas Sawa Kabupaten Konawe Utara Tahun 2017.

Hall, H. G., Beattie, J., Lau, R., East, C. \& Anne, M. (2016) Mindfulness and perinatal mental health: a systematic review. Women Birth, 29 (1): 62-71

Katona, Cornelius, Claudia Cooper, Mary Robertson. 2012. At a Glance Psikiatri Edisi Keempat. Jakarta: EGC

Notoatmodjo. 2010. Ilmu Perilaku Kesehatan. Jakarta : PT. Rineka Cipta.

Pairman, Sally. 2011. Midwifery: Preparation for Practice 2nd ed. Australia: Elsevier

Rubertsson, C., Hellström, J., Cross, M. \& Sydsjö, G. (2014) Anxiety in early pregnancy: prevalence and contributing factors. Arch Womens Ment Health, 17 (3): 221-8

Shindu P. (2009). Yoga Untuk Kehamilan. Sehat, Bahagia \& Penuh Makna. Bandung

Shiraishi, J. C., Mara, L. \& Bezerra, A. (2016) Complementary therapies in clinical practice effects of yoga practice on muscular endurance in young women. Complement Ther Clin Pract, 22: 69-73

Streeter, C. C., Gerbarg, P. L., Saper, R. B., Ciraulo, D. A. \& Brown, R. P. (2012) Effects of yoga on the autonomic nervous system, gammaaminobutyricacid, and allostasis in epilepsy, depression, and post-traumatic stress disorder. Med Hypotheses, 78 (5): 571-9.

Team trainer Prenatal Gentle Yoga. Modul Prenatal Gentle Yoga.

Varney, H., Kriebs, J. M. \& Gegor, C. L. (2010) Varney's midwifery. Fourth edition. Jakarta: EGC 
Vijayalakshmi, $\quad$ P., Madanmohan., Bhavanani, A. B., Patil, A. \& Kumar, B. P. (2004) Modulation of stress induced by isometric handgrip test in hypertensive patients following yogic relaxation training. Indian $\mathrm{J}$ Physiol Pharmacol, 48 (1): 59-64.

Wawan, A dan Dewi. 2011. Teori dan Pengukuran Pengetahuan, Sikap, dan Perilaku Manusia. Penerbit Nuha Medika. Yogyakarta.

Wiadnyana. (2011). Panduan Praktis Yoga pada Masa Kehamilan dan Pascapersalinan. Jakarta : PT Gramedia Widiasarana. 